\title{
CHALLENGING CRITICAL AND CREATIVE THINKING IN FOREIGN LANGUAGE TEACHING AND LEARNING
}

\author{
Raisa Gladushyna
}

doi: 10.18355/PG.2019.8.1.7

\begin{abstract}
Knowledge and skills are the basic values in human life in the modern information society. Developing critical thinking and applying creativity into foreign language teaching and learning is becoming more and more important for educators. In this paper the ideas of how English classes may contribute to the development of critical and creative thinking skills are suggested. The paper shares both theoretical and practical ideas about critical and creative thinking development within English language teaching and learning. It begins by examining the need for the teaching of thinking skills in preparation of students as $21^{\text {st }}$-century learners. The paper provides a literature overview to shed light on the nature of critical thinking and creativity root notions. The survey method is used as a model. A few examples of classroom activities where critical and creative thinking are highlighted are considered. From the survey results, perceptions and attitudes of students to the process of learning English as a foreign language are described. The research demonstrates the positive development of critical and creative thinking outcomes for most students exposed to the presented teaching technique.
\end{abstract}

\section{Key words}

critical thinking, creativity, activities, English language teaching and learning

\section{Introduction}

In recent years more than ever a person has been exposed to a large amount of human knowledge. Living in the information or knowledge society implies dealing with a continuously increasing wealth of information on a daily basis. The ability to use information skillfully and appropriately requires high mental and intellectual skills. The $21^{\text {st }}$-century skills are different from those of the $20^{\text {th }}$ century primarily due to the emergence of very sophisticated information and communication technologies. All fields of knowledge are dynamic in nature. Modern technologies challenge foreign language teachers to prepare students with the strategies they need to be effective in academic, business and social settings.

The P21 organization (the Partnership for $21^{\text {st }}$ Century Learning) conducted research that identified deeper learning competencies and skills they called the Four $\mathrm{Cs}$ of the $21^{\text {st }}$-century learning: collaboration, communication, critical thinking, and creativity. These competencies indicate sufficiency of knowledge and skills that a person needs to act in a wide variety of contexts. There is an array of intellectual skills and the most important among them are 
critical thinking and creativity.

The terms "critical thinking" and "creative thinking" progressively appear in the world of education and foreign language teaching and learning. Didem and Hürsen (2013) chose and analyzed 141 articles related to critical thinking in the database of EBSCO, Science Direct, Tyler Francis and Ulakbim. Critical thinking studies were grouped from the publishing year 2000-2013. They revealed that most of the critical thinking studies were done in the area of education, and there are 83 of such studies related to critical thinking in the educational realm.

Globalization substantially changes the course of university studies. Therefore, the education system should be adopted in the current world. Nowadays, the main target of higher education institutions is to instruct the students to be flexible, productive, creative and possess critical thinking ability. This points out the importance of critical thinking and creativity in education. Despite a great number of researches on critical thinking and creativity, numerous studies mention that university graduates lack fundamental soft skills, namely critical and creative thinking, decisionmaking and problem-solving that are extremely important for their successful, professional career. Though critical thinking is being identified as an important educational objective, there is strong evidence indicating that many college graduates lack critical thinking skills needed for future success in the modern workplace (Ahuna et al., 2014; Nold, 2017).

Fell and Lukianova (2015) also shared similar insights while investigating

British academics' perception of international students' alleged lack of critical thinking. Kahneman and Egan (2011) elaborated further and stated that there was ample evidence that many adults, including college students, consistently fall prey to flawed and biased thinking. Carson (2015) and Sawyer (2013) asserted that critical and creative thinking skills are not limited to the few geniuses who are born with it, but these higher-order thinking skills can be developed through practice, feedback, and reflection.

Thus, the following urgent questions arise: how to incorporate critical thinking and creativity into foreign language setting as well as how to promote the development of higher-order cognition within foreign language teaching and learning in a university setting.

\section{Literature review}

Human learning is a complex phenomenon. The cognitive domain involves knowledge and the development of intellectual skills. Knowledge and skills are of paramount importance in the information society as they outline the type of professional training of students as future teachers of English as a foreign language. They enhance the intellectual and moral development of the students' personality, stimulates their potential, forms critical and creative thinking. The question of the theoretical foundation is very important in the establishment of a proper educational environment to make an English language class an effective thinking space favorable for incorporating and developing critical and creative thinking skills. 


\subsection{What is the nature of critical thinking?}

Both critical and creative thinking are viewed under the umbrella of higher order thinking skills. Nevertheless, some scholars, researchers consider them completely different. There are the consensus and mutual understanding of the importance of critical thinking in the new knowledge society, and that critical thinking skills are not restricted to a subject. According to Kelly (2009), critical thinking has become a concept that is important for all subject domains.

Despite the unanimity among researchers on the role of critical thinking, this type of thinking does not enjoy common definition either there is agreement on its nature. One reason is that critical thinking is a complex concept which is at the core of most intellectual activity and involves sophisticated cognitive processes. Critical thinking develops higher order thinking skills (HOTS) analysis - evaluation - synthesis. Higher order thinking is based on varies taxonomies on learning, particularly the one created by Benjamin Bloom (1956). Bloom's taxonomy was revised by his former student Lorin Anderson. In 2001, Anderson worked with D. Krathwohl and others and published a Revised Bloom's Taxonomy which showcases student actions (verb forms) versus nouns in the original Bloom's taxonomy. The taxonomy reflects different forms of thinking, and as thinking is an active process, verbs were used rather than nouns.

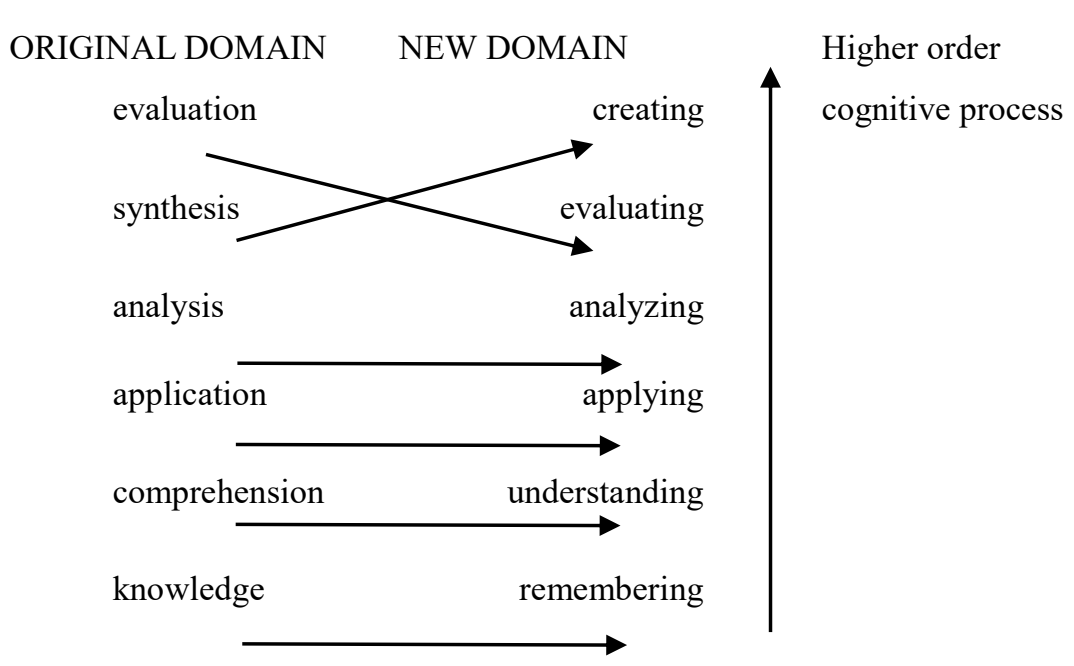

Picture 1. Revised Bloom's Taxonomy (Source: Clark, 2013)

Taxonomy reflects the forms of thinking. It should be stressed that knowledge, comprehension (remembering, understanding) are factual questions and are not considered as critical thinking. The upper levels of the taxonomy represent critical thinking. While Bloom's taxonomy does not reflect all the interplays of the thinking process, it is a valuable tool for Slavonic Pedagogical Studies Journal, eISSN 1339-9055, ISSN 1339-8660, Volume 8 Issue 1, 2019 
looking at the cognitive aspects of it. Thus, the original domain and new domain of the taxonomy represent a handy set of skills necessary for thinking critically. It echoes Sternberg's (1986: 3) definition of critical thinking as "the mental processes, strategies, and representations people use to solve problems, make decisions and learn new notions". Ennis (1985) denotes critical thinking as reflective and reasonable thinking that is focused on deciding what to believe or do. Delecce (2018) argues that "critical thinking means making reasoned judgments that are logical and well-thought out. It is a way of thinking in which you don't simply accept all arguments and conclusions you are exposed to but rather have an attitude involving questioning such arguments and conclusions". It requires wanting to see what evidence is involved in supporting an argument or conclusion. According to Paul and Elder (2008), critical thinking is that mode of thinking - about any subject, content or problem - in which thinkers improve the quality of the processing their way of thinking competently when they are aware of principal mechanisms of thinking.

Even with different approaches to the definition of critical thinking, there is a common ground that critical thinking implies formulating questions clearly, making logical judgments, seeking reason, problem-solving, decisionmaking. Liu, Frankel, and Roohr (2014) evaluated seven critical frameworks to identify common elements. In their evaluation results, they stated that critical thinking entails such primary mental operations, namely identifying, analyzing, synthesizing, and evaluating, which are basic for practical knowledge of problem-solving and decision-making.

There is, however, a debate among scholars on the relationship between the two types of thinking. Some view them as different but complementary. Glaser (1985) states "creativity supplements critical thinking. It may not be an essential ingredient in critical thinking". Halpern (2003) also describes critical and creative thinking as complementary and similar but not identical processes. Beyer (1995) argues that "critical thinking is not making decisions or solving problems. It is not the same as reflective thinking, creative thinking, or conceptualizing. Each of these other types of thinking serves a specific purpose".

Only by understanding whether there is a relationship between critical and creative thinking, if in fact these two extremely important constructs are interconnected, teachers will be able to challenge their students to develop critical and creative thinking skills.

\subsection{What is the architecture of creative thinking?}

The notion of creative thinking is also understood and interpreted in different ways. The term "creative" recalls related terms such as "creativity", "creative thinking", "creative thinking skills", "creativeness". Creativity can be defined in multiple ways, involving cognitive processes, personality characteristics, environment variables as well as the interaction of these components (Kaufman et al., 2008; Sternberg, 2006). Creativity is often used to denote a more universal conception of creativeness. Harris (2018) sets it out in terms of three main components: ability, attitude, and process. Perkins (1988) 
suggests that the products of creative thought (sometimes referred to as divergent thought) usually have both originality and appropriateness.

Peter Facione (2018) views creativity or innovative thinking as the kind of thinking that leads to new insights, novel approaches, fresh perspectives, whole new ways of understanding and conceiving of things. Creative thinking involves analytical thinking skills, flexibility, originality, brainstorming, metaphorical thinking, communication, creative problem solving and so on. Taylor (1959), an authority in the field of creative thinking, distinguished between five types of creativity: expressive creativity, productive creativity, inventive creativity, innovative creativity, and imaginative creativity.

The main distinguishing features of critical and creative thinking proposed by Robert Harris (2018). In his view, these two kinds of thinking should be differentiated as it is illustrated in the table below.

Table 1. Critical thinking vs. creative thinking

\begin{tabular}{|l|l|}
\hline Critical thinking & Creative thinking \\
\hline analytical & generative \\
\hline convergent & divergent \\
\hline vertical & lateral \\
\hline probability & possibility \\
\hline judgment & suspended judgment \\
\hline focused & diffuse \\
\hline objective & subjective \\
\hline the answer & an answer \\
\hline left brain & right brain \\
\hline verbal & visual \\
\hline linear & associative \\
\hline reasoning & richness, novelty \\
\hline yes, but & yes and \\
\hline algorithmic & heuristic \\
\hline solution path & solution paths \\
\hline
\end{tabular}

\subsection{The relationship between critical and creative thinking}

While there has been much debate about the definition and nature of critical and creative thinking, little discussion has taken place concerning the relationship of critical and creative thinking. The question arises whether they 
are entirely different or there is a correlation between critical and creative thinking.

Paul and Elder (2012) stress that the very definition of the word "creative" implies a critical component (e.g. "having or showing imagination and artistic or intellectual inventiveness"). Scriven (1976: 124) states that "the very process of criticism necessarily involves the creative activity of generating new theories or hypotheses to explain phenomena that have seemed to other people to admit of only one explanation".

Padget (2012) says creativity and creative thinking go hand in hand and help to provide different ways of making sense of a situation; after applying analytical and logical thinking while dealing with the problem, the solution is possible by involving creative thinking. This is the place where creative and critical thinking meet as we then go on to assess whether the solution we have arrived at is the best solution available.

Nevertheless, Harris (2018) postulated the distinguishing features of critical and creative thinking. He analyses the way they operate and makes a conclusion that both types of thinking are interrelated to one another in mental activities. He states that "in an activity like problem-solving, both kinds of thinking are important to us". First, we must analyze the problem; then we must generate possible solutions; next we must choose and implement the best solution; and finally, we must evaluate the effectiveness of the solution. As you can see, this process reveals an alteration between the two kinds of thinking, critical and creative. In everyday practice, critical and creative thinking function concurrently and they are not in fact unconventional.

Paul and Elder (2006) echo Harris's understanding of the relationship of critical and creative thinking when they say that "the critical and creative functions of the mind are so interwoven that neither can be separated from the other without an essential loss to both". Indeed, sound thinking requires both imagination and intellectual standards. Paul and Elder (2012) also assume that "imagination and reason are an inseparable teams. They function best in tandem, as the right and left legs in walking and running".

Thus, critical and creative thinking are not independent modes of thinking which function within different contexts. Rather they are inseparably linked and are both involved in the process of thinking well in any area. Both critical and creative thinking are achievements of thought. Critical thinking is performed after creating thinking has generated various possibilities. Creativity masters a process of making or producing. Criticality masters a process of assessing or judging (Paul and Elder, 2012).

It is the nature of the mind to produce thoughts. Thinking is a higher cognitive process, mental activities to transform reality, create a new product, find new solutions to existing problems. Our mind, especially our thoughts, affect our perception and therefore, our interpretation of reality. Creativity is closely related to critical thinking, they work together. Creative thinking is generative whereas critical thinking is analytical. It can be illustrated by the function of two hemispheres (sides) of our brain.

The left side of the brain controls the right side of the body. It also performs tasks that have to do with judgment, reasoning, probability. On the other 
hand, the right side coordinates the left side of the body and performs tasks that deal with creativity, novelty. To sum up, critical and creative thinking can be viewed as intimately related dynamic notions; as being effective and challenging tools in the process of teaching and learning.

\subsection{Strategies and activities promoting critical and creative thinking in foreign language teaching and learning}

The problem of development of student's critical and creative thinking skills in the process of teaching and learning a foreign language is reflected in numerous studies on enhancing the cognitive and creative activity of students (Davidson, 1994; Hughes, 2014; Sieglova, 2017; Starko, 2014). Today, there are a lot of different strategies, techniques, and activities which can be used to support motivation and challenge creativity, boost critical thinking in the group of foreign language learners. Teaching a foreign language itself is a creative and exciting endeavor. The use of creative techniques and activities capable of promoting and developing critical thinking is necessary for teaching and learning foreign languages.

Students can be taught strategies for critical thinking skills that enable them to handle information more effectively and efficiently, think logically, analyze and compare, recognize different points of view and assumptions. Then they will be able to demonstrate habits of mind or thinking behaviors in different contexts. Creativity at a foreign language class helps students to introduce and share new ideas, develop and use foreign language speaking skills, be responsible for their decisions and form a positive attitude to foreign language.

In order to anchor critical and creative thinking in a foreign language classroom, teachers are to be aware of not WHAT to teach but HOW to learn. To have more learner-centered classes, teacher's position is important, but a bit changed from the controller to facilitator, helper. The teacher should not be superior to students, rather they both are seeking strategies and activities of how best to teach and learn English as a foreign language. The role of a teacher is to arrange the learning process, create a learning environment, organize a favorable space of thinking.

It is extremely important to use teaching strategies and activities which foster the development of both critical and creative thinking in students. Neve (1986: 146) offers seven principles for creating a classroom which is "braincompatible" and "far removed from the standard teacher-talking-at-passivegroup model".

1. Provide a non-threatening climate.

2. Provide a huge amount of input.

3. Emphasize genuine communication.

4. Provide for much manipulation.

5. Emphasize reality.

6. Address learning activities to actual, productive uses.

7. Respect natural thinking.

Creativity is seen as an important quality for university students, future 
professionals. In this regard, Beghetto and Kaufman (2007) offered a conceptual model of the Four C Model of Creativity. The model describes the four levels of creative expression:

- Big C: this type of creativity only applies to what is completely new for the people and is thus most closely associated with genius.

- Little C: this is creativity in every day problem-solving.

- Mini C: creativity associated with learning. When absorbing information, humans do not simply absorb it, but rather they process it through a filter of personal experience. How creative one is in applying this filter is referred to as mini $\mathrm{C}$.

- Pro C: Pro C, or professional creativity, is creativity at the workplace. Some people may be professionally active as creators, but they do not fall under the big $\mathrm{C}$ category because some of their work may already exist elsewhere in humanity.

Mini $\mathrm{C}$ is defined as the novel and personally meaningful interpretation of experiences, actions, and events. Central to the definition of mini C creativity is the dynamic process of constructing personal knowledge. The four $\mathrm{C}$ model provides a framework for incorporating creativity in the teaching and learning process and helps students to develop their creativity to higher levels.

\section{Objectives and research questions}

104 Based on the nature of the study, three main research aims were stated for dealing with the issue:

- To develop students' awareness of critical and creating thinking.

- To explore the effect of critical and creative thinking on students' attitude about learning English as a foreign language.

- To adapt some strategies and activities for developing comprehensive critical and creative thinking skills.

The study was guided by the following three research questions:

1. What strategies may improve students' higher order thinking skills in English foreign language teaching and learning?

2. What are the most effective tools available for a teacher to organize a favorable thinking space in a foreign language classroom?

3. What is the impact of critical and creative thinking on teaching and learning English as a foreign language?

\section{Methods}

The aim of this study is to determine the relationship between critical and creative thinking skills and find out effective strategies and activities which might challenge and enhance students' thinking skills in the process of teaching and learning English as a foreign language. Students' preferences for classroom activities and their previous language experience were also explored. The study followed collecting numerical data through a 10 -item 
questionnaire. The study was also carried out to provide insights into the setting of the issue under investigation, to find out thoughts and opinions of students towards different methods and activities of learning English as a foreign language, to determine cognitive creativity in learning a foreign language.

To achieve the objectives two methods were used. The primary data for the study were got from the questionnaire and observation during English classes. Literature overview has been a helpful and constructive input for the study.

\subsection{Participants}

The participants of this study were the fourth-year students, future teachers of English language and literature, at a Ukrainian higher education institution. The study was carried out with 32 students, 27 female and 5 male participants. Students' level of English ranged from B1 to B2 of the Common European Framework (CEF). Students have English language classes four times a week. The study was carried out during one semester.

\subsection{Procedure and instruments}

Students were given a questionnaire. There were ten questions for them to answer. The purpose of this questionnaire was to get the students' feedback. Within the questions students evaluated their previous language learning experience, the English course, different strategies and activities, their perception and attitudes towards these activities.

In carrying out classroom strategies and activities Elliot's (1991) action model was used. According to this model the teacher plans, acts, observes, and reflects upon the pedagogical experience. This procedure indicates that action research started with raising a question that identifies the problem under investigation. The teacher-learning process is viewed as an intellectual process with a focus on development and enhancing critical and creative thinking skills. The stages of the action model are listed below:

1. Planning. The problem was identified - the students need more "braincompatible" classes, strategies and activities aimed at promoting critical and creative thinking.

2. Action. According to the data obtained from the phase of planning the research plan was put into motion. The activities were chosen to be implemented into the English language classes. The action plan was put into practice during one semester and the chosen activities were regularly used in English classes.

3. Observation. Observation focused on whether the students found the activities challenging, interesting and motivating, whether the activities developed better language skills, communicative skills and thinking skills as well. The collected data were processed, and the activities were evaluated.

4. Reflection. At this stage, the action was evaluated in order to understand what has happened to plan. An overall conclusion was made. Thus, the students were given an opportunity to improve their critical thinking skills, 
develop their creative potential and apply language knowledge.

In the study, the following thinking techniques were used. SCAMPER is one of the most well-known brainstorming techniques (Eberie, 1996). The students were introduced to divergent thinking and SCAMPER as a technique for fostering divergent thinking. It was systematically used in English language classes. The SCAMPER brainstorming technique uses a set of directed questions to resolve a problem.

- Substitute: Who or what could you substitute, swap or use instead?

- Combine: Who or what can you bring together?

- Adapt: Who or what (parts of the process) could you change?

- Modify: How could you distort, reshape, maximize or minimize parts of the whole?

- Put to another use: How might these apply in other circumstances? How could it be used by someone else or for other purposes?

- Eliminate: What if you remove a component or forego the usual way of doing?

- Reverse/rearrange: What if you did this the other way around? How could you achieve the opposite effect?

DO IT technique (Olson,1980) was also applied in the course of the study. The name is based on the following abbreviation: Define-Open-IdentifyTransform. The pattern of the DO IT process emphasizes the need to define problems, open yourself to many possible solutions, identify the best solution and then transform it into action effectively. It is used for quick problem solving and designed to accelerate and strengthen a person's natural creative problem-solving ability and to stimulate many diverse ideas for solutions to the problem.

Socratic questioning techniques. Socratic questioning is the core of critical thinking (Paul and Elder, 2007). The usage of the Socratic approach to questioning helps to practice the ability to participate in a logically structured dialogue. The list of question and question categories is as follows:

1. Questions for clarification:

a. Why do you say that?

b. How does it relate to our discussion?

2. Questions that probe assumptions:

a. What can we assume instead?

b. How can you verify or disapprove that assumption?

3. Questions that probe reason and evidence:

a. What would be an example?

b. What is ... analogs to?

4. Questions about viewpoints and perspectives:

a. What would be an alternative?

b. What is another way to look at it?

5. Questioning that probe implications and consequences:

a. What generalization can you make?

b. What are you implying?

6. Questions about the question:

a. What was the point of this question? 
b. Why do you think I ask this question?

The Socratic technique is an effective way to deeply explore ideas. It is a helpful tool for teachers. Higher order thinking skills are present while learners think, discuss, debate, evaluate, and analyze content through. The purpose of Socratic Questioning is to challenge the accuracy and completeness of thinking.

\section{Results}

The study has shown that critical and creative thinking are issues that are to be addressed and focused on in an English foreign language classroom. The study demonstrated that critical and creative thinking are not fostered in the typical English language classroom. The questionnaire revealed that most students were not aware of critical and creating thinking. It was also found out that students are eager to deal with critical and creative thinking techniques during English classes. Findings of the study also suggest that class discussion with using specific techniques can challenge and enhance critical and creative thinking.

It was also revealed that students evaluate more easily information, make arguments, comprehend and retain ideas when they debate on them, probe their assumptions, compare their ideas in pair work or group discussion. This is supported by empirical evidence which suggests that information that is actively processed rather than merely "recorded", is more readily retrieved from memory, more accessible for application to new situations, and less likely to be forgotten (Bransford, 1979).

If the open discussion and feedback from the group take place in the English language classroom, it helps to organize a favorable space for critical thinking and creativity. Ennis (1987) also argues that critical thinking is a practical activity that includes creative actions such as raising questions, formulating a hypothesis, generating alternatives, and making plans about gathering information.

Theoretical findings and empirical studies supported the idea about the interrelation of critical and creative thinking. As to creative thinking it overlaps with critical thinking. Thinking about the explanation of some phenomenon or event requires creative imagination (Bailin, 1988).

\section{Conclusion}

Implementing critical and creative thinking techniques within English foreign classes will be beneficial for both teachers and learners. To develop critically and creating thinking it is necessary to consider the types of activities and techniques from the point of view of how they contribute both to the intellectual and to the affective development of students. Teachers can encourage and help students become more creative. Critical and creative thinking is essential for productive thinking and learning.

Critical and creative thinking are communicative processes that develop reason, logic and imagination. Communication is integral to each of the 
thinking processes. Through critical and creative thinking students learn independently and make their own decisions in various educational contexts. Both thinking skills provide students with a more skillful way of communication, enable them to acquire new knowledge, and deal with ideas, beliefs, and attitudes.

If students are provided a proper educational environment, they develop and foster critical thinking: the ability to analyze, compare, contrast and evaluate and creative thinking, improving their fluency, flexibility and originality. Becoming an educated thinker will help students achieve their life and career goals and be successful.

\section{Bibliographic references}

AHUNA, K. et al. 2014. A new era of critical thinking in professional programmes. In Transformative Dialogues: Teaching and Learning Journal, 7(3). pp. 1-9.

ANDERSON, L. - KRATHWOHL, D. et al. A Taxonomy for Learning, Teaching, and Assessing. A Revision of Bloom's Taxonomy of Educational Objectives. Addison. Wesley. Longman, Inc.

BAILIN, S. 1988. Achieving Extraordinary Ends: An Essay in Creativity. Dordrecht: Kluver doi:10.1007/978-94-009-2780-3.

BEGHETTO, R., KAUFMAN, J. 2007. Toward a Broader Conception of Creativity: A C ase for mini-c Creativity. In Psychology of Aesthetics creativity and the Arts 1(2), pp. 73-79. DOI: 10.1037/1931-3896.1.2.73.

BEYER, B. 1995. Critical Tthinking. Phi Delta Kappa Educational Foundation. Bloomington, Indiana p.93.

BLOOM, B. 1956. Taxonomy of Educational Objectives: The Classification of Educational Goals. Handbook 1, Cognitive Domain. New York: David McKay.

BRANSFORD, J. 1979. Human Cognition: Learning Understanding and Remembering. Belmont, CA: Wadsworth.

CARSON, S. 2015. Targeting Critical Thinking Skills in a First-Year Undergraduate Research Course. In Journal of Microbiology and Biology Education, 16(2), pp.148-156.

CLARK, D. 2013. Bloom's Taxonomy of Learning Domains [online]. Available at: http://ww.nwlink.com/ᄀDOUCLARK/HTD/BLOOM.HTML

DAVIDSON, B. 1994. Critical thinking: A perspective and prescriptions for language teachers. In The Language Teacher, 18(4), pp. 41-53.

DELLECE, T. 2018. What is Critical Thinking? Definition, Skills and Meaning . Available online: https://study.com/acdemy/lesson/what-iscriticalthinking-definition -skills-meaning.html.

DIDEM, I. - CIGDEM, H. 2013. Evaluation of Critical Thinking Studies In Terms of Content Analysis. WCETR. In Procedia-Social and Behavioral Sciences, 131, pp. 290-299.

EBERIE, B. 1996. Scamper: Games for Imagination Development. Prufrock Press Inc.

ELLIOT, J. 1991. Action research for educational change. Buckingham, UK: Open University Press.

ENNIS, R. 1985. The logical basis for measuring critical thinking skills. In 
Educational Leadership, 43(2): pp. 44-48.

ENNIS, R. 1987. A taxonomy of critical thinking dispositions and abilities. In Teaching Thinking Skills: Theory and Practice. (J.B. Baron, R.J. Sternberg eds.) New York.

FACIONE, P. 2018. Creative Thinking Skills for Education and Life (teaching creativity) Available online: https://www.asa3.org/ASA/education/think/creative.htm

FELL, E. - LUKIANOVA, N. 2015. British Universities: International Students' Alleged Lack of Critical Thinking. In Procedia-Social and Behavioral Sciences, 215, pp.2-8.

GLASER, E. 1985. Critical Thinking: Educating for Responsible Citizenship in a Democracy Educating for responsible citizenship in a democracy. In National Forum, vol. 65, no. 1, pp. 24. Honor Society of Phi Kappa Phi.

HALPERN, D. 2003. Thought and knowledge: An introduction to critical thinking $\left(4^{\text {th }}\right.$ edn). Lawrence Erlbaum, Hillsdale, NJ.

HARRIS, R. 2018. Introduction of Creative thinking . Available online: http://www.virtualsalt.com/crebookl.

HUGHES, J. 2014. Critical Thinking in the Language Classroom . Available online: https://www.ettoi.pl/PDF_resourses/Critical_ThinkingENG.pdf.

KAHNEMAN, D. - EGAN, P. 2011. Thinking, fast and slow. New York, US: Farrar, Straus and Giroux.

KAUFMAN,G. et al. 2008. Essentials of creativity assessment. Hoboken. NY: Wiley.

KELLY, Y. 2009. Assessing students' critical thinking performance: Urging for measurements using multi-response format. Thinking Skills and Creativity, 4, pp. 70-76. G

LIU, O. et al. 2014. Assessing critical thinking in higher education: current state and direction for next-generation assessment. ETS Research Reports Series, 2014(1), pp. 1-23. doi:10.1002/ets2.12009.

NEVE, C.1986. High learning jumps show potency of brain-based instruction. In Phi Delta Kappan, 68(2), pp.143-48.

NOLD, H. 2017. Using Critical Thinking Teaching Methods to Increase Student Success: An Action Research Project. International Journal of Teaching and Learning in Higher Education, 29(1), pp.17-32.

OLSON, D. 1980. On the Language and Authority of Textbooks. Journal of Communication, 30(1), pp.186-196.

PADGET, S. 2012. Creativity and Critical Thinking. Routledge.

PAUL, R. - ELDER, L. 2008. The miniature guide to critical thinking concepts and tools. Dealon Beach, CA: Foundation for Critical Thinking.

PAUL, R. - ELDER, L. 2006. Critical Thinking: The Nature of Critical and Creative Thought. In Journal of Development Education, 30(2).

PAUL, R. - ELDER, L. 2007. Critical thinking. The art of Socratic questioning. In Journal of Developmental Education, 31(1), pp. 32-37.

PAUL,R. - ELDER, L. 2012. Critical Thinking: Tools for taking charge of Your Learning and Your Life (3rd Ed.). Pearson. ISBN-13:9780132180917. PERKINS, D. 1988. Creativity and the quest for mechanism. In RJ Sternberg and EE Smith (eds.), In The Psychology of Human Thought, pp. 309-336. New York: Cambridge University Press. 
SAWYER, K. 2013. Zig Zag: The Surprising Path to Greater Creativity. John Wiley \& Sons.

SCRIVEN, M. 1976. Reasoning. New York: McGraw-Hill.

SIEGLOVA, D. 2017. Critical Thinking for Language Learning and Teaching: Methods for the 21st Century. In Cross-Cultural Business Conference 2017, p. 189. 2017.

STARKO, A. 2014. Creativity in the classroom: schools of curious delight. New York: Routledge.

STERNBERG, J. 2006. The nature of creativity. Creativity Research Journal, 18(1), pp. 87-98. http://dx.doi. org/.1207/s15326934crj1801.10.

STERNBERG, R.1986. Critical thinking: Its nature measurement, and improvement. National Institute of Education . Available online: http://eric.ed.gov/PDES?ED272882.pdf

TAYLOR, A. 1959. The nature of the creative process. In P. Smith, Creativity. Hastings House. New York, pp.51-82.

Raisa Gladushyna

Borys Grinchenko Kyiv University

18/2, Bulvarno-Kudriavska St

Kyiv

Ukraine

r.hladushyna@kubg.edu.ua 